\title{
Introduction of Safflower as an Oilseed Crop in the Central Region of the Russian Federation
}

ISSN: 2637-7659

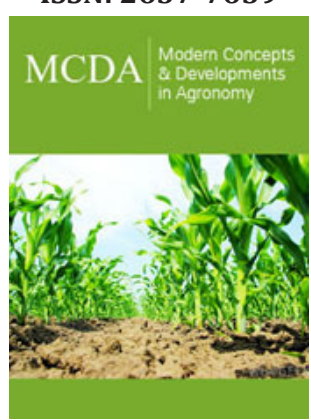

*Corresponding author: Sulukhan Temirbekova, All-Russian Research Institute of Phytopathology, Russia

Submission: 漹 August 18, 2021

Published: 侮August 24, 2021

Volume 9 - Issue 2

How to cite this article: Sulukhan Temirbekova, Yuliya Afanaseva. Introduction of Safflower as an Oilseed Crop in the Central Region of the Russian Federation. Mod Concep Dev Agrono. 9(2). MCDA. 000710.2021. DOI: 10.31031/MCDA.2021.09.000710

Copyright@ Sulukhan Temirbekova. This article is distributed under the terms of the Creative Commons Attribution 4.0 International License, which permits unrestricted use and redistribution provided that the original author and source are credited.

\section{Sulukhan Temirbekova ${ }^{1 *}$ and Yuliya Afanaseva ${ }^{2}$}

${ }^{1}$ All-Russian Research Institute of Phytopathology, Russia

${ }^{2}$ Federal Scientific Selection and Technology Center for Horticulture and Nursery, Russia

\section{Opinion}

At the moment seeds oil content increasing selection have become major assets of our agricultural production, such as the property becomes a breeding for oil quality change. It has been shown that each variety and even the shape of the population are composed of a larger or smaller number of biotypes differing by number of features, including the concentration of the fatty acid oil [1]. The basis in the selection to the quality of oil for technical and food use is the knowledge of genotypic variability of the fatty acids composition in the range of cultivated species and wild relatives. N.I. Vavilov attached great importance to the study of differentiation within the species for chemical signs of quality grades [2,3] repeatedly emphasizing need to identify genetic differences that can be seen in the study in the same conditions of different varieties in different geographical locations.

Qualitative differences are determined by genetic characteristics of oil varieties and forms. Oils quality features can be enhanced by content increasing of main fatty acids (oleic and linoleic).

For the first time, the biological, morphological and phenological peculiarities of the introduced new culture of tinctorial safflower in the Central region of the Russian Federation were studied. The results of the research in the Lower Volga and North Caucasus regions are also presented. The optimal parameters of the depth of seeding $(5-6 \mathrm{~cm})$, seeding rates $(300$ 350 thousand units per hectare or $12-14 \mathrm{~kg}$ ), ensuring high productivity, oil content and quality of seeds, have been established. There was revealed the relationship between the moisture supply of the vegetation periods with the accumulation of oil content and a change in the fatty acid composition. The oil content of raw seeds in the mentioned regions varied from 14.5 to 31.2\%; and in the year 2013 that was excessively humid, it comprised 6.4\% in the Moscow region and 8.6\%-in the Saratov region. In the fatty acid composition of the Krasa Stupinskaya safflower variety, oleic acid content varied between 13.6 and $6.8 \%$ and linoleic acid contentbetween 68.5 and $75.7 \%$. Its oil yield in the conditions of Moscow region was $240 \mathrm{~kg} / \mathrm{ha}$. The yielding capacity of the Krasa Stupinskaya variety comprised 0.6t/ha in the Moscow region, $0.8 \mathrm{t} / \mathrm{ha}$ in the Rostov region and 1.2t/ha in the Saratov region, with an average weight of 1000 seeds, respectively, by region: 40, 47.3 and 40.9g. The vegetation period was 105 days for the Moscow region, 94 -for the Rostov region and 95 days-for the Saratov region.

It has been established that over wetting while blossoming and seed filling increases the negative effect of enzyme-mycotic depletion of seeds (EMDS)-biological trauma at the root (enzyme stage), followed by the colonization of seeds with the phytopathogen Alternaria carthami Chowdhury. High antioxidant activity of the leaves and petals of safflower dyeing 
was revealed, which plays an important role in protecting the plant from abiotic (drought, over wetting) and biotic (diseases, weeds) stressors. The regularity of a decrease in the cadmium content in safflower seeds in relation to other plant organs is noted: its content in seeds is 5-15 times less than in leaves and 3-5 times less than in root. The performed studies have proved the effectiveness of new-generation herbicides such as the Dual Gold soil herbicide and the Harmony spayed herbicide. The last has proved to be especially effective while branching and had a stimulation effect on the growth of safflower.

The performed studies have made it possible to obtain the pattern source to be used for further breeding. Two safflower varieties have been created for the Central region of the Russian Federation. An adaptive technology to grow the oilseed crop of tinctorial safflower-the Krasa Stupinskaya variety, was elaborated for this region.
The safflower advantage is its earlier, almost a month, maturing compared with the sunflower culture. It provides rhythmic delivery of raw materials to the oil mills. Created safflower cultivar Krasa Stupinskaya quickly adapt to contrasting soil and climatic conditions of the regions.

\section{References}

1. Temirbekova SK, Afanasyeva YuV, Kurilo AA (2016) Adaptive technology of cultivation of oilseed safflower cultivar Krasa Stupinskaya in bioorganic agriculture. Recommendations. Agrorus, Moscow, Russia, p. 64.

2. Vavilov NI (1967) Selection as a science. Selected Works, Leningrad, Russia, 1: 328-343.

3. Temirbekova SK, Afanasyeva YuV, Kulikov IM (2020) Introduction of safflower (Carthamus Tinctorius L.) in Russian Central Nonchernozem Belt: monograph. p. 148.

For possible submissions Click below: 